\title{
Health, nutrition and hydration status of Indonesian workers: a preliminary study in two different environmental settings
}

\author{
Saptawati Bardosono, ${ }^{1}$ Ermita Ilyas ${ }^{2}$ \\ ${ }^{1}$ Department Nutrition, Faculty of Medicine, Universitas Indonesia, Jakarta, Indonesia \\ ${ }^{2}$ Department Physiology, Faculty of Medicine, Universitas Indonesia, Jakarta, Indonesia
}

\begin{abstract}
Abstrak
Latar belakang: Status hidrasi di lingkungan kerja suhu tinggi maupun suhu sejuk dapat mempengaruhi status kesehatan pekerja. Penelitian ini bertujuan untuk mengetahui status kesehatan, status gizi dan status hidrasi pekerja di dua lingkungan kerja yang berbeda.
\end{abstract}

Metode: Studi potong lintang komparatif dipilih dengan melibatkan dua kelompok pekerja pabrik, masing-masing terdiri dari 39 orang laki-laki sehat berusia 25-45 tahun dari dua lingkungan kerja yang berbeda, yaitu yang terpapar langsung dengan suhu tinggi dan yang bekerja di ruangan bersuhu sejuk. Data yang diperoleh meliputi data hasil pemeriksaan fisik, berat, tinggi badan, lingkar pinggang dan komposisi lemak tubuh serta data laboratorium. Data disajikan secara deskriptif sebagai nilai tengah dan proporsi; analisa statistik dengan uji-t tidak berpasangan (MannWhitney) dan chi-square digunakan untuk membandingkan data kedua kelompok subjek.

Hasil: Subjekyang terpapar panas berisiko lebih mengalami dehidrasi dibanding yang tidak terpapar panas, terlihat dari lebih tingginya beberapa penanda status hidrasi secara bermakna, yaitu kadar hemoglobin (15,6 vs 14,8 mg/dL, $p=$ 0,017), hematokrit (46 vs 44\%, $p=0,040)$, viskositas darah (23 vs $12 \mathrm{mEq} / \mathrm{L}, p<0,001)$, dan kadar natrium darah (140 vs $138 \mathrm{mEq} / \mathrm{L}, p<0,001)$. Sebaliknya, subjek yang tidak terpapar panas dan hanya duduk mengerjakan tugas administrasi mempunyai kadar kolesterol HDL yang lebih rendah secara bermakna (43 vs 52,1 $\mathrm{mg} / \mathrm{dL}, \mathrm{p}=0,005)$, dan mempunyai persentase komposisi lemak tubuh dan lemak viseral yang lebih tinggi secara bermakna dibanding subjek terpapar panas yang hampir selalu berdiri dan bergerak melaksanakan pekerjaannya $(21,6 \%$ vs $17,6 \%, p=0,008$ dan $10 \%$ vs $8 \%, p=0,015$ ).

Kesimpulan: Pekerja di dua lingkungan kerja berbeda (panas dan sejuk) berisiko terhadap masalah kesehatan, masalah gizi dan masalah dehidrasi sehingga perlu perhatian khusus terhadap asupan cairan serta aktivitas fisik yang memadai.

\begin{abstract}
Background: Hydration status in the working environment of hot and conveniently cool may influence the health status of workers, including their hydration status. This study aimed to determine the health, nutrition and hydration status of workers in two different working environment, i.e. hot and conveniently cool environment.

Methods: A cross-sectional comparative study was done on apparently healthy male subjects, age 25-45 years. Two groups of factory workers consisted of 39 subjects working in environment exposed directly to heat and the other doing administrative work in cool environment. Data on their health status (physical examination), weight, height, waist circumference, fat body composition, laboratory result, were collected. The data was presented as average value and proportion; statistical analysis with unpaired-t (Mann-Whitney test) and chi-square test was used.
\end{abstract}

Results: Subjects working in a hot environment were more prone to dehydration in comparison to their counterparts, as was shown by significantly higher values of several hydration status biomarkers: hemoglobin (15.6 vs $14.8 \mathrm{~g} /$ $\mathrm{dL}, \mathrm{p}=0.017$ ), hematocrit (46 vs 44.5\%, $\mathrm{p}=0.040$ ), blood viscosity (23 vs $12 \mathrm{mEq} / \mathrm{L}, \mathrm{p}<0.001$ ), and blood sodium concentration (140 vs $138 \mathrm{mEq} / \mathrm{L}, \mathrm{p}<0.001)$. In contrast, subjects working in a conveniently cool environment who did more administrative tasks were physically less active, had significantly lower HDL-cholesterol level (43 vs $52.1 \mathrm{mg} / \mathrm{dL}, \mathrm{p}=0.005)$, higher body and visceral fat compositions (21.6 vs $17.6 \%, \mathrm{p}=0.008$, and 10 vs $8 \%$, $\mathrm{p}=0.015$, respectively) compared to their counterparts.

Conclusion: Workers in hot and cool working environment are prone to nutrition- and health problems as well as dehydration, suggesting special attention to the provision of timely drinking water, and physical activity during working time.

Keywords: health, hydration, nutrition, working environment

pISSN: 0853-1773•eISSN: 2252-8083• http://dx.doi.org/10.13181/mji.v23i2.993• Med J Indones. 2014;23:112-6

Correspondence author: Saptawati Bardosono, tati.bardo@yahoo.com

Copyright @ 2014 Authors. This is an open access article distributed under the terms of the Creative Commons Attribution-NonCommercial-ShareAlike 4.0 International License (http://creativecommons.org/licenses/by-nc-sa/4.0/), which permits unrestricted non-commercial use, distribution, and reproduction in any medium, provided the original author and source are properly cited. 
Health and nutritional status of workers is certainly affecting their performance and productivity. ${ }^{1,2}$ Acute and chronic diseases, as well as under- and overweight/ obesity, are common problems among workers which are preventable. Special attention should be drawn to health-screening and timely monitoring, including health education to workers, especially those working at higher risk, e.g. in hot environment. ${ }^{3}$

In Indonesia, the workers undergo at least yearly medical check-up. However, the follow-up is merely providing medicine or supplements. Health and nutritional promotion and education is the least important in the work place. Hypertension and dyslipidemia are amongst health problems found during the medical check-up that needs health and nutrition counseling. ${ }^{4}$ Furthermore, hydration status is considered not important in the work place. ${ }^{5,6}$ There are several diseases related to chronic systemic mild dehydration, namely urolithiasis, urinary tract infection, bladder and colon cancer, constipation, hypertension and other cardiovascular diseases. ${ }^{7}$

Workings in hot environment such as in industrial setting, cause dehydration because of high sweat rate, $1 \mathrm{~L}$ per hour, especially if body fluids are not adequately replenished during and after the period of heat exposure. This is the reason why dehydration should be included in health and safety concerns as it will reduce the work performance. ${ }^{5}$ This study was performed to identify the health, nutrition and hydration status among male Indonesian workers in hot and cool working environments.

\section{METHODS}

\section{Design study}

A cross-sectional comparative study design was applied to compare the health-, nutrition- and hydration status of Indonesian workers in two factories in Cibitung, West-Java, i.e. the hot and conveniently cool working environments.

\section{Subjects}

Subjects were recruited from two selected factories, 39 subjects per group for each working environment, following the study criteria: apparently healthy males aged 25-45 year, working approximately for 8 hours/day, not having renal disease and diabetes mellitus based on their latest general check-up, willing to participate in the study and gave informed consent. Ethical clearance was obtained from the Ethical Committee Faculty of Medicine Universitas Indonesia (No. 30/PT02/FK/ETIK/2012, January 18, 2012).

\section{Sample size}

In conducting a preliminary study, this study recruited 39 subjects per group for each environmental condition or 78 subjects for the total sample. The selected subjects were classified according to their environmental temperature by using total population sampling technique.

\section{Study procedure}

\section{Interview}

Subjects were interviewed about their sociodemographic characteristics, employment duration, and medical history.

\section{Anthropometric measurement}

Anthropometric measurements including weight, height, waist circumference, and body compositions were done using standard instruments. All measurements were done in the morning before the blood withdrawn, using type 571 Tanita weighing scale for weight and body composition, Seca 206 and Seca 201 for height and waist circumference, respectively.

\section{Vital sign measurement}

Blood pressure was measured using Reister Anova sphygmomanometer in a sitting position, and heart rate was taken by counting the pulse of Radialis artery per-minute manually.

\section{Laboratory measurements}

Blood and urine were taken in the morning before the subjects started to work by Prodia Laboratory. Blood tests consisted of hemoglobin, hematocrit, blood viscosity, lipid profile, blood electrolytes and urine test were urine color, $\mathrm{pH}$, specific gravity, and electrolytes.

\section{Data management and analysis}

Data were recorded using special forms and collected between $6^{\text {th }}$ of January and $3^{\text {rd }}$ of February 2012. 
Data were edited, coded, and submitted into working sheets in the computer using SPSS version 20. Statistical analyses were performed and data were presented into descriptive and analytical approaches to confirm the hypothesis using unpaired-t test and/ or Mann-Whitney test.

\section{RESULTS}

A total sample of 39 subjects per working environment was eligible in this study. During study observation, it was found that those working in hot environment are mostly in standing position and keeps moving to process the production materials. In contrast, those working in the conveniently cool environment, mostly did administrative work, sitting most of the time, rarely moved their bodies, unless they went to other places for a meeting or having breaks.

Table 1 shows that the subjects had similar age and duration of working time in the factory however had different working hours. Subjects working in the cool environment had significantly less working hours than those in the hot environment, consequently the latter was exposed more to heat. There were no significant differences in blood pressure, heart rate, triglyceride, total and LDLcholesterol levels, however those working in the conveniently cool environment had significantly lower HDL-cholesterol levels.

Table 2 shows analysis of the nutritional status between the two groups. It revealed that workers in hot working environment had significantly lower body and visceral fat contents than those in the cool working environment. The body mass index (BMI) and waist circumference were also less however the difference was not statistically significant. More than $50 \%$ of workers in both working environments were overweight and obese (BMI $\geq 23.0 \mathrm{~kg} / \mathrm{m}^{2}$ ) where $23 \%$ of those working in the hot environment and $41 \%$ in the cool environment had abdominal obesity (waist circumference $\geq 90 \mathrm{~cm}$ ).

Analysis of hydration status of the two groups showed that the water content was significantly higher among workers in the hot environment than those in the conveniently cool environment. This consistently related to the inversed correlation between percentages of body fat to body water suggesting that the higher percentage of body fat will be followed by the lower body water content. $^{8}$

Although the workers in hot working environment had significantly higher body water content, $79.5 \%$

Table 1. The health status of the subjects in hot and cool working environments

\begin{tabular}{|c|c|c|c|}
\hline Variables & $\begin{array}{l}\text { Hot environment } \\
(\mathrm{n}=39)\end{array}$ & $\begin{array}{l}\text { Cool environment } \\
(\mathrm{n}=39)\end{array}$ & $\mathrm{p}$ \\
\hline Age (year) & $29(25-44)^{\S}$ & $30(25-45)^{\S}$ & $0.086^{*}$ \\
\hline Duration of working (years) & $8(1-22)^{\S}$ & $8(1-30)^{\S}$ & $0.695^{*}$ \\
\hline Working hours/day (hours) & $12(8-12)$ & $8(7-12)$ & $<0.001^{*}$ \\
\hline \multicolumn{4}{|l|}{ Blood pressure $(\mathrm{mmHg})$ : } \\
\hline Systolic & $110(90-160)^{\S}$ & $120(80-150)^{\S}$ & $0.243^{*}$ \\
\hline High risk (> $139 \mathrm{mmHg}), \mathrm{n}(\%)$ & $3(7.7)$ & $3(7.7)$ & $1.000^{\dagger}$ \\
\hline Diastolic & $80(60-100)^{\S}$ & $80(60-100)^{\S}$ & $0.949^{*}$ \\
\hline High risk (> $89 \mathrm{mmHg}), \mathrm{n}(\%)$ & 0 & 0 & - \\
\hline Heart rate (times/minute) & $68(60-88)^{\S}$ & $72(60-88)^{\S}$ & $0.426^{*}$ \\
\hline Total-cholesterol (mg/dL) & $189.2(31.8)^{\prime}$ & $194.6(29.9)^{\natural}$ & $0.444^{*}$ \\
\hline High risk (> 239 mg/dL), n (\%) & $11(28.2)$ & $19(48.7)$ & $0.063^{\dagger}$ \\
\hline Triglycerides (mg/dL) & $91(34-263)^{\S}$ & $103(37-341)^{\S}$ & $0.054^{*}$ \\
\hline High risk $(>200 \mathrm{mg} / \mathrm{dL})$ & $8(20.5)$ & $12(30.8)$ & $0.300^{\dagger}$ \\
\hline LDL-cholesterol (mg/dL), n (\%) & $126.6(32.4)^{\prime}$ & $126.8(25.2)^{\prime}$ & $0.972 \ddagger$ \\
\hline High risk (> $130 \mathrm{mg} / \mathrm{dLk})$ & $35(89.7)$ & $32(82.1)$ & $0.329^{\dagger}$ \\
\hline HDL-cholesterol (mg/dL), n (\%) & $52.1(12.6)^{1}$ & $43(27-96)^{\S}$ & $0.005^{*}$ \\
\hline High risk $(<45 \mathrm{mg} / \mathrm{dL})$ & $7(17.9)$ & $14(35.9)$ & $0.074^{\dagger}$ \\
\hline
\end{tabular}

"Mann-Whitney U test; ${ }^{\star}$ chi-square-test; ${ }^{\star}$ unpaired-t test; ${ }^{\S}$ median (minimum-maximum); 'mean (SD) 
of them had high blood viscosity versus $25.6 \%$ working in conveniently cool environment. This finding was supported by other hydration biomarkers such as hemoglobin concentration, hematocrit, blood viscosity and blood sodium concentration which were significantly higher among workers in hot environment (Table 3).

\section{DISCUSSION}

This study aimed to assess the health, nutrition and hydration status of workers in hot and conveniently cool working environment. It was conducted in two factories with room temperature of $36-38^{\circ} \mathrm{C}$ and $20-22^{\circ} \mathrm{C}$.

Table 2. Nutritional status of the subjects in hot and cool working environments

\begin{tabular}{|c|c|c|c|}
\hline Variables & $\begin{array}{l}\text { Hot environment } \\
\quad(\mathrm{n}=39)\end{array}$ & $\begin{array}{l}\text { Cool environment } \\
\quad(\mathrm{n}=39)\end{array}$ & $\mathrm{p}$ \\
\hline Body weight in $\mathrm{kg}$, mean (SD) & $64.81(11.93)$ & $68.97(11.99)$ & $0.129^{*}$ \\
\hline Fat in $\%$, mean $(\mathrm{SD})$ & $17.61(6.71)$ & $21.65(6.31)$ & $0.008^{*}$ \\
\hline Water in $\%$, median (min-max) & $60.1(25.4-68.2)$ & $57.0(48.7-66.9)$ & $0.022^{\dagger}$ \\
\hline Visceral fat in $\%$, median (min-max) & $8(1-19)$ & $10(1-16)$ & $0.015^{\dagger}$ \\
\hline Muscle mass in $\%$, mean (SD) & $50.01(6.12)$ & $50.86(5.64)$ & $0.526^{*}$ \\
\hline Bone mass in $\%$, mean (SD) & $2.74(0.33)$ & $2.77(0.28)$ & $0.631^{*}$ \\
\hline Basal metabolic rate in kcal, mean (SD) & $1484.38(196.65)$ & $1503.46(181.19)$ & $0.657^{*}$ \\
\hline Height in m, median (min-max) & $1.67(1.55-1.87)$ & $1.66(1.57-1.83)$ & $0.682^{\dagger}$ \\
\hline Body mass index in $\mathrm{kg} / \mathrm{m} 2$, mean (SD) & $23.58(4.82)$ & $24.83(4.24)$ & $0.227^{*}$ \\
\hline Thin $(<18.5), \mathrm{n}(\%)$ & $4(10.3)$ & $3(7.7)$ & \\
\hline Normal (18.5 - 22.9), n (\%) & $14(35.9)$ & $8(20.5)$ & \\
\hline Overweight (23.0 - 24.9), n (\%) & $9(23.1)$ & $9(23.1)$ & \\
\hline Obese $(\geq 25.0), \mathrm{n}(\%)$ & $12(30.8)$ & $19(48.7)$ & $0.556^{\ddagger}$ \\
\hline Waist-circumference in $\mathrm{cm}$, mean (SD) & $82.75(10.44)$ & $87.47(11.10)$ & $0.057^{*}$ \\
\hline Abdominal obesity $(\geq 90 \mathrm{~cm}), \mathrm{n}(\%)$ & $9(23.1)$ & $16(41.0)$ & $0.089^{\S}$ \\
\hline
\end{tabular}

"independent-t test; "Mann-Whitney U test; ${ }^{*}$ Kolmogorov-Smirnov test; ${ }^{\circledR}$ chi-square-test

Table 3. Hydration status of workers in hot and cool working environments

\begin{tabular}{|c|c|c|c|}
\hline Variables & $\begin{array}{l}\text { Hot environment } \\
(\mathrm{n}=39)\end{array}$ & $\begin{array}{l}\text { Cool environment } \\
(\mathrm{n}=39)\end{array}$ & $\mathrm{p}$ \\
\hline Hemoglobin in g/dL, median (min-max) & $15.6(12.3-18.0)$ & $14.8(12.6-17.2)$ & $0.017^{*}$ \\
\hline Anemia, n (\%) & $3(7.7)$ & $1(2.6)$ & $0.615^{\dagger}$ \\
\hline Hematocrit in $\%$, median (min-max) & $46(39-49)$ & $44(40-49)$ & $0.040^{*}$ \\
\hline Less than normal, $\mathrm{n}(\%)$ & $1(2.6)$ & - & $1.000^{\dagger}$ \\
\hline Blood viscosity, mean (SD) & $22.99(8.21)$ & $11.99(2.18)$ & $<0.001^{\ddagger}$ \\
\hline High blood viscosity, n (\%) & $31(79.5)$ & $10(25.6)$ & $<0.001^{\S}$ \\
\hline Blood Na, median (min-max) & $140(136-145)$ & $138(135-141)$ & $<0.001^{*}$ \\
\hline Hyponatremia, n (\%) & - & $1(2,6)$ & $1.000^{\S}$ \\
\hline \multicolumn{4}{|l|}{ Urine color, n (\%) } \\
\hline Pale yellow & $3(7.7)$ & $6(15.4)$ & $1.000^{\S}$ \\
\hline Yellow & $25(64.1)$ & $23(59)$ & $1.000^{\S}$ \\
\hline Dark yellow & - & $1(2.6)$ & $1.000^{\S}$ \\
\hline Amber & $11(28.2)$ & $9(23.1)$ & $1.000^{\S}$ \\
\hline Urine $\mathrm{pH}$, median (min-max) & $6(5-7)$ & $6(5-8)$ & $0.233^{*}$ \\
\hline Urine $\mathrm{pH}$ status, $\mathrm{n}(\%)$ & All normal & All normal & \\
\hline Urine specific gravity (USG), mean (SD) & $1.0178(0.0076)$ & $1.0187(0.0077)$ & $0.626^{\ddagger}$ \\
\hline USG status, n (\%) & All normal & All normal & \\
\hline
\end{tabular}

"Mann-Whitney U test; ${ }^{\dagger}$ chi-square test; ${ }^{*}$ independent-t test; ${ }^{\$}$ Kolmogorov-Smirnov test 
There were no significant differences in the blood pressure, heart rate, triglyceride, total and LDLcholesterol levels between the two groups of workers except that those working in the conveniently cool environment had significantly lower HDLcholesterol level. This was possibly due to longer working hours and more physical activities happened among the workers in hot environment. It is well known that higher physical activity will decrease the risk factors for CVD, including the plasma lipids and lipoproteins. Evidence showed that increasing physical activity was associated with the increase level of HDL and decrease of triglycerides. ${ }^{9}$

The overall health status of the workers in this study suggested they were at high risk of dyslipidemia, which is potentially related to coronary heart disease (CHD). Several studies revealed that CHD risk correlates to HDL-cholesterol level than to other blood lipid parameters since HDL plays a role in transferring circulating cholesterol to the liver; thus lowering the blood cholesterol level. Lower HDL-cholesterol level is evidently showing inverse association with the risk for coronary heart disease (CHD); while HDL-cholesterol level is much related to daily life style, i.e. mostly is aerobic exercise and diet. $^{10}$

Nutritional status of the workers in both working environment showed that overweight, obesity and abdominal obesity, as determined by BMI and waist circumference, were highly prevalent among them. Instead of BMI, abdominal obesity has been reported to be a good indicator for the risk of developing cardio-vascular diseases (CVD). ${ }^{11}$ Individuals with low BMI but having excess waist circumference, representing intra-abdominal (visceral) adiposity, may not be detected on the basis of BMI alone.

Blood viscosity is one physiological marker to determine both acute and chronic dehydration status, whereas urine specific gravity relates more to chronic dehydration. ${ }^{12}$ Our study showed that individuals working in hot environment were at higher risk to develop both acute and chronic dehydration. While acute dehydration can be reversed by providing sufficient fluid intakes, chronic dehydration may lead to organ damage such as deposits of the blood vessels and kidney stone.
In conclusion, this preliminary study shows that workers in hot and cool working environment are prone to metabolic health problems as well as dehydration, suggesting special attention to the provision of timely drinking water, and physical activity during working time are required.

\section{Conflict of interest}

Dr. Bardosono reports grants from PT Amerta Indah Otsuka, during the conduct of the study.

\section{REFERENCES}

1. Dieleman M, Harnmeijer JW. Improving health worker performance: in search of promising practices. Geneva: World Health Organization; 2006.

2. Katsuro P, Gadzirayi CT, Taruwona M, Mupararano S. Impact of occupational health and safety on worker productivity: A case of Zimbabwe food industry. Afr J Bus Manage. 2010;4(14):2644-51.

3. Seppänen O, Fisk WJ, Lei QH. Effect of temperature on task performance in office environment. Barkeley (CA): Lawrence Berkeley National Laboratory, Environmental Energy Technologies Division; 2006 July. Report No.: LBNL60496. Sponsored by the Department of Energy.

4. Bankole AR, Ibrahim LO. Perceived influence of health education on occupational health of factory workers in Lagos State, Nigeria. British Journal of Arts and Social Sciences 2012;8(1):57-65.

5. Hunt AP. Symptoms of Heat Illness in Surface Mine Workers. Int Arch Occup Environ Health. 2013;86(5):519-27.

6. Bates GP, Miller VS, Joubert DM. Hydration status of expatriate manual workers during summer in the Middle East. Ann Occup Hyg. 2010;54(2):137-43.

7. Manz F. Hydration and disease. J Am Coll Nutr. 2007;26(5):535S-41S.

8. Wang ZM, Deurenberg P, Wang W, Pietrobelli A, Baumgartner RN, Heymsfield SB. Hydration of fatfree body mass: review and critique of a classic bodycomposition constant. Am J Clin Nutr. 1999;69(5):833-41.

9. Monda KL, Ballantyne, CM and North, KE. Longitudinal impact of physical activity on lipid profiles in middle-aged adults: The Atherosclerosis Risk in Communities Study. J Lipid Res. 2009;50(8):1685-91.

10. Miller M. Raising an isolated low HDL-C level: Why, how, and when? Cleve Clin J Med. 2003;70(6):553-60.

11. Despre's JP. Abdominal obesity: the most prevalent cause of the metabolic syndrome and related cardiometabolic risk. Eur Heart J Suppl. 2006;8 (Suppl B):B4-12.

12. Sawka MN, Burke LM, Eichner ER, Maughan RJ, Montain SJ, Stachenfeld NS. Special communication: Exercise and fluid replacement. Medicine \& Science in Sports \& Exercise 2007;39(2):377-90. 